\section{Treatment emergent affective switch with topiramate}

Indução de mania associada ao tratamento com topiramato

\section{Dear Editor,}

Topiramate is a novel anticonvulsant that has been used for bipolar disorder. However, no clear evidence of efficacy was found in clinical trials. More recently, topiramate has been used for the management of weight gain associated with the use of mood stabilizer and atypical antipsychotics.

There are only two reported cases of treatment emergent affective switch (TEAS) to mania or hypomania associated with the use of topiramate. ${ }^{1-2}$ These patients were using topiramate for treatment of epilepsy and had no previous diagnosis of bipolar disorder. In this letter we report the emergence of manic symptoms within a period of one month after the introduction of topiramate in the pharmacological treatment of two euthymic patients previously diagnosed with bipolar disorder.

The medical records of all outpatients treated in our Bipolar Disorder Research Program from 1997 to 2004 were retrospectively analyzed. Out of a total of 123 outpatients, 34 received topiramate combined with mood stabilizers and/or atypical antipsychotics. For the diagnosis of topiramateassociated TEAS it was required the fulfillment of DSM-IV criteria for a manic or hypomanic episode and a Young Mania Rating Scale (YMRS) total score equal to or greater than 12 .

Four patients (11.7\%) presented TEAS but only two $(5.8 \%)$ during the first month of treatment with topiramate, which represents a more rigorous criterion for TEAS. ${ }^{3}$

Case 1: A 56-year-old female was in remission for two months, on lithium carbonate $900 \mathrm{mg} /$ day, carbamazepine $600 \mathrm{mg} /$ day and olanzapine $20 \mathrm{mg} /$ day. One week after introducing topiramate for weight loss, the patient presented insomnia, irritability, increased rate of speech and motor agitation, fulfilling criteria for a hypomanic episode. Her YMRS score changed from 1 (before topiramate introduction) to 14 points. Topiramate was discontinued and olanzapine was increased up to $25 \mathrm{mg} /$ day, with remission of the episode after two weeks

Case 2: A 40-year-old male was in remission for 12 months, on lithium carbonate $2100 \mathrm{mg} /$ day. Topiramate was introduced for treatment of obesity. The patient lost $7 \mathrm{~kg}$ in the course of one month of treatment, but presented insomnia, racing thoughts, irritability, aggressiveness, talkativeness and motor excitement, fulfilling criteria for a manic episode. His YMRS score increased from 2 (before topiramate introduction) to 29 points. Topiramate was discontinued, and olanzapine plus clonazepam were introduced. The patient and his family decided to seek treatment in a different service and he was lost to follow-up.

Topiramate has been used mainly as an add-on drug in acute and prophylactic treatment of bipolar disorder, especially for weight loss. To our knowledge this is the first report of bipolar patients taking topiramate who presented TEAS. We detected a $5.8 \%$ incidence of TEAS in our sample, using a strict diagnosis criterion. Since topiramate has been widely used for weight loss, we think it is very important to study its safety and tolerability, specially the incidence of TEAS. Data from placebo controlled double-blind topiramate studies should be analyzed. Prospective trials may help to shed light in this issue.

Renata Sayuri Tamada, Jose Antonio de Mello Siqueira Amaral, Cilly Kluger Issler, Beny Lafer Bipolar Disorder Research Program (PROMAN), Institute of Psychiatry, Universidade de São Paulo Medical School, São Paulo (SP), Brazil

Financing: None

Conflict of interests: None

References

1. Schlatter FJ, Soutullo CA, Cervera-Enguix S. First break of mania associated with topiramate treatment. J Clin Psychopharmacol. $2001 ; 21(4): 464-6$.

2. Jochum T, Bar KJ, Sauer H. Topiramate induced manic episode. J Neurol Neurosurg Psychiatry. 2002;73(2):208-9.

3. Tamada RS, Issler CK, Amaral JA, Sachs GS, Lafer B. Treatment emergent affective switch: a controlled study. Bipolar Disord. $2004 ; 6(4): 333-7$

\section{Association study between the 1287 A/G exonic polymorphism of the norepinephrine transporter (NET) gene and obsessive- compulsive disorder in a Brazilian sample}

Estudo da associação entre o polimorfismo exônico 1287 A/G do gene transportador da norepinefrina e o transtorno obsessivo-compulsivo em uma amostra brasileira

Dear Editor,

Obsessive-compulsive disorder (OCD) is a chronic, severely debilitating anxiety disorder, characterized by intrusive and senseless thoughts and impulses (obsessions) and by repetitive behaviors or mental acts (compulsions), with a lifetime prevalence of 2 to $3 \%$. Data from family, twin and segregation studies have shown that genetic factors contribute to the expression of the disorder. ${ }^{1}$ An essential step to understanding the genetics of OCD is the localization and characterization of the genes that confer susceptibility to the disorder.

Since there are reports that some drugs used in the treatment of OCD, like clomipramine and venlafaxine, act on the noradrenergic system among other systems ${ }^{2}$ and that young unmedicated OCD subjects excrete in the urine more adrenaline and homovanillic acid than healthy controls, ${ }^{3}$ it is hypothesized that the noradrenergic system may be related to the pathophysiology of OCD. Therefore, the norepinephrine transporter (NET) gene became a candidate target for genetic studies of this disorder. To our knowledge, there is no previous investigation of the NET gene as a susceptibility gene for OCD.

NET is a 617-amino acid protein and its gene (SLC6A2) is located on chromosome 16q.12.2, consisting of 14 exons 
(protein coding regions). ${ }^{4}$ The silent polymorphism $1287 \mathrm{~A} /$ G (rs5569), located in the exon 9, has been previously studied in other psychiatric disorders, such as schizophrenia, bipolar disorder, major depression, Tourette syndrome and panic disorder. These investigations produced inconclusive results so far.

The present study investigated the $1287 \mathrm{~A} / \mathrm{G}$ variant (rs5569) in 75 DSM-IV OCD patients and 317 matched healthy controls. This study was previously approved by the Clinical Hospital Ethics Committee and all participants gave their written informed consent. Genomic DNA was extracted from venous blood samples and the exonic silent polymorphism (1287 A/G - rs5569) was analyzed as described by Jönsson et al. ${ }^{5}$ PCR products were resolved on $2 \%$ agarose gels and visualized by ultra-violate light after ethidium bromide staining. We used a chi-square test for the analysis of the differences of allele and genotype frequencies between OCD patients and controls.

The genotypic distributions were in Hardy-Weinberg equilibrium. We did not find differences in the allelic $\left(O R=1.140 .74<O R<1.75 ; X^{2}=0.38 ; 1\right.$ d.f.; $\left.p=0.53\right)$ and genotypic ( $X^{2}=0.51 ; 2$ d.f.; $p=0.77$ ) distributions (Table 1 ). Our results do not support the association between the $1287 \mathrm{~A} / \mathrm{G}$ polymorphism in the NET gene with OCD in our Brazilian sample.

Table 1 - Allelic and genotyoic distribution of the norepinephrine transporter gene

\begin{tabular}{lcccc}
\hline & OCD & Controls & $x^{2}$ & p value \\
\cline { 2 - 5 } ALLELES & \multicolumn{5}{c}{0.38} & 0.53 \\
\hline A & $113(75.33)$ & $462(72.87)$ & 0.38 \\
G & $37(24.66)$ & $172(27.12)$ & & \\
Total & $150(100)$ & $634(100)$ & & \\
\hline GENOTYPES & & & \\
\hline AA & $42(56.00)$ & $169(53.31)$ & 0.51 & 0.77 \\
AG & $29(38.66)$ & $124(39.11)$ & & \\
GG & $4(5.33)$ & $24(7.57)$ & & \\
Total & $75(100)$ & $317(100)$ & & \\
\hline
\end{tabular}

Acknowledgments

This work was supported by grants from Fundação de Amparo à Pesquisa do Estado de São Paulo (FAPESP) to Vallada $\mathrm{H}$ and Miguel EC and from Coordenação de Aperfeiçoamento de Pessoal de Nível Superior (CAPES) to Miguita K.

Karen Miguita, Quirino Cordeiro, Roseli Gedanke Shavitt, Euripedes Constantino Miguel, Homero Vallada

Department of Psychiatry, Clinical Hospital, Medical School, Universidade de São Paulo (USP), São Paulo (SP), Brazil

Financing: Fundação de Amparo à Pesquisa do Estado de São Paulo (FAPESP) (grant \# 99/08560-6); and Coordenação de Aperfeiçoamento de Pessoal de Nível Superior (CAPES) (number \# 8817)

Conflict of interests: None

\section{References}

1. Hounie AG, Brotto AS, Diniz J, Chacon PJ, Miguel EC. Transtorno obsessivo-compulsivo: possíveis subtipos. Rev Bras Psiquiatr. 2001;23(Supl2):13-6.
2. Albert U, Aguglia E, Maina G, Bogetto F. Venlafaxine versus clomipramine in the treatment of obsessive-compulsive disorder: a preliminary single-blind, 12-week, controlled study. J Clin Psychiatry. 2002;63(11):1004-9.

3. Oades RD, Ropcke B, Eggers C. Monoamine activity reflected in urine of young patients with obsessive compulsive disorder, psychosis with and without reality distortion and healthy subjects: an explorative analysis. J Neural Transm Gen Sect. 1994;96(2): 143-59.

4. Bruss M, Kunz J, Lingen B, Bonisch H. Chromosomal mapping of the human gene for the tricyclic antidepressant-sensitive noradrenaline transporter. Hum Genet. 1993;91(3):278-80.

5. Jonsson EG, Nothen MM, Gustavsson JP, Neidt H, Bunzel R, Propping P, Sedvall GC. Polymorphisms in the dopamine, serotonin, and norepinephrine transporter genes and their relationships to monoamine metabolite concentrations in CSF of healthy volunteers. Psychiatry Res. 1998;79(1):1-9.

\section{Importância dos aspectos culturais em um caso com agitação psicomotora}

Cultural aspects importance in a case with psychomotor agitation

\section{Sr. Editor,}

A globalização tem derrubado as fronteiras mundiais. Tem colocado os médicos da atualidade em contato mais freqüente com pacientes de diferentes etnias e culturas. Segundo Konner, diferentes atitudes, conhecimentos e condutas são necessários para a prática clínica neste novo século. ${ }^{1}$ Em virtude desse fato passou-se a dar importância a psiquiatria transcultural, que pode fornecer as ferramentas para diagnóstico e tratamento efetivo através da remoção das barreiras culturais e lingüísticas. ${ }^{1}$ Relatamos o caso de uma paciente de 32 anos, casada, com prendas domésticas, natural e procedente de Menongue, Angola. A paciente foi levada por amigos ao Pronto Socorro da Santa Casa de Misericórdia de São Paulo após um período de 6 horas de alteração de comportamento. Segundo os acompanhantes, ela teria sido possuída pelo demônio, tornando-se muda e isolada, evoluindo posteriormente com agitação e estado de transe. Durante avaliação inicial, a paciente foi colocada no leito, adotando posturas de contorção corporal e revirando os olhos para cima. Passou a falar de modo rápido e incompreensível, o que foi inicialmente interpretado como jargonofasia. No entanto, logo foi constatado que se tratava do dialeto de uma região do país de origem. 0 exame físico não apresentava alterações. Os exames laboratoriais eram normais. Foi realizada radiografia de abdômen no intuito de encontrar algum corpo estranho (como porte de drogas), porém sem achados. Os acompanhantes informaram que a paciente, apesar de morar em Angola, não falava português, pois esta língua é um diferencial socioeconômico naquele país e a ela provinha de uma classe social desfavorecida. Estava no Brasil há dois dias, nunca havia ficado longe do marido e demonstrava grande preocupação pelo fato dele ter outras mulheres. Foi medicada com 2,5 mg de haloperidol, com melhora significativa dos sintomas após 1 hora, quando referiu não saber o que havia acontecido. Os acompanhantes descreveram outros episódios semelhantes no passado, todos em situações de estresse.

0 presente caso evidencia a necessidade da equipe médica observar aspectos transculturais na doença mental. Foi possível observar uma paciente, recém chegada ao Brasil, admitida no Pronto Socorro com quadro de agitação. A primeira 